\title{
AKTIVITAS ANTIOKSIDAN EKSTRAK KAPANG ENDOFIT Cb.Gm.B3 ASAL RANTING KAYU MANIS (Cinnamomum burmanni)
}

\section{Antioxidant Activity of Endophytic Fungi Cb.Gm.B3 Extract from Cinnamon (Cinnamomum burmanni) Twigs}

\author{
Fauzy Rachman $^{1,3}$, Nisa Rachmania Mubarik ${ }^{2}$, Partomuan Simanjuntak ${ }^{3, *}$ \\ 1 Departemen Bioteknologi, Gd. PAU, Institut Pertanian Bogor, JI. Kamper, Bogor, 16680, Indonesia \\ ${ }^{2}$ Departemen Biologi, Fakultas Matematika dan IImu Pengetahuan Alam, Institut Pertanian Bogor, Bogor, 16680, Indonesia \\ ${ }^{3}$ Pusat Peneliban Bioteknologi, Lembaga IImu Pengetahuan Indonesian, Jl. Raya Bogor Km46, Cibinong, Bogor, 16911, Indonesia \\ *Email: partomsimanjuntak@gmail.com
}

\begin{abstract}
There are many degenerative diseases that are caused by a free radical effect. Cinnamon (Cinnamomum burmanni) contains cinnamaldehyde compounds that have activity as a powerful antioxidant and fight free radicals. Endophytic fungi can be found in cinnamon plants living symbiotically. Endophytic fungi produce a variety of bioactive metabolites including antioxidants. This research was conducted to isolate endophytic fungi from C. burmanni plant which is active as antioxidant. Endophytic fungi isolation was carried out using surface sterilization method and cultivated in PDA media. Antioxidant activity test was performed using free radical 2.2-diphenyl-1-picrylhydrazyl (DPPH) method. Selected isolates were then identified molecularly to determine their species. A total of nine fungi were isolated from cinnamon twigs. The result showed that the highest antioxidant activity was obtained from Cb.Gm.B3 with IC50 of $13.219 \pm 0.755 \mu \mathrm{g} / \mathrm{mL}$. The selected isolate Cb.Gm.B3 taxonomically has a high similarity with Neofusicoccum parvum isolate PEL23 (Accession no: KY053054.1).
\end{abstract}

Keywords: antioxidant, Cinnamomum burmanni, 2.2-diphenyl-1-picrylhydrazyl, endophytic fungi, Neofusicoccum parvum

\begin{abstract}
ABSTRAK
Kayu manis (Cinnamomum burmanni) mengandung senyawa sinamaldehid yang memiliki aktivitas sebagai antioksidan kuat dan dapat menangkal radikal bebas. Dalam tanaman kayu manis terdapat kapang endofit yang hidup bersimbiosis. Kapang endofit dapat menghasilkan berbagai senyawa metabolit bioaktif termasuk antioksidan. Penelitian ini dilakukan untuk mengisolasi kapang endofit dari tanaman C. burmanni yang aktif sebagai antioksidan. Isolasi kapang endofit dilakukan menggunakan metode sterilisasi permukaan dan ditanam pada media PDA. Pengujian aktivitas antioksidan dilakukan menggunakan metode peredaman radikal bebas dengan reagen 2.2-difenil-1-pikrilhidrazil (DPPH). Isolat terpilih diidentifikasi secara molekuler untuk menentukan spesiesnya. Sebanyak 9 isolat kapang berhasil diisolasi dari jaringan ranting tanaman kayu manis. Aktivitas antioksidan tertinggi $\left(\mathrm{IC}_{50}\right)$ didapatkan dari isolat Cb.Gm.B3 sebesar 13,219 $\pm 0,755 \mu \mathrm{g} / \mathrm{mL}$. Isolat terpilih Cb.Gm.B3 secara taksonomi memiliki tingkat kemiripan yang tinggi dengan Neofusicoccum parvum isolat PEL23 (No. aksesi: KY053054.1).
\end{abstract}

Kata Kunci: antioksidan, Cinnamomum burmanni, 2.2-difenil-1-pikrilhidrazil, kapang endofit, Neofusicoccum parvum 


\section{PENDAHULUAN}

Tanaman kayu manis (Cinnamomum burmanni) merupakan penghasil kulit kayu untuk bahan baku rempah. Hasil sampingan pada saat panen berupa batang, daun dan ranting juga dapat dimanfaatkan menjadi beragam produk bernilai ekonomis. Prospek tanaman kayu manis di masa depan akan semakin baik sejalan dengan makin bertambahnya penduduk, diketahuinya kandungan kimia pada kayu manis dan manfaatnya untuk industri farmasi, kosmetika, makanan dan minuman (Ferry 2013).

Banyak senyawa metabolit sekunder yang dihasilkan oleh tanaman memiliki efek sebagai obat suatu penyakit. Kayu manis (C. burmanni) dipercaya merupakan salah satu sumber antioksidan yang dapat melawan radikal bebas dalam tubuh. Menurut Priani et al. (2014), salah satu tumbuhan yang diketahui mengandung senyawa dengan aktivitas antioksidan yang sangat kuat adalah kayu manis. Kulit batang kayu manis mengandung senyawa sinamaldehid yang memiliki aktivitas sebagai antioksidan yang sangat kuat yang secara efektif dapat melawan radikal bebas termasuk anion superoksida dan hidroksi-radikal, demikian pula radikal bebas yang lainnya dalam pengujian in vitro (Jakhetia et al. 2010).

Tanaman juga memiliki kapang yang bersimbiosis di dalam organ tanaman yang disebut sebagai kapang endofit. Kapang endofit merupakan kapang yang hidup di dalam jaringan tanaman yang mempunyai peranan menguntungkan kepada inangnya dengan cara menghasilkan senyawa bioaktif untuk perlindungan terhadap cekaman biotik dan abiotik (Dai et al. 2008). Setiap tumbuhan tingkat tinggi dapat mengandung lebih dari satu mikroba endofit yang mampu menghasilkan senyawa biologi (Dudeja et al. 2012) ataupun metabolit sekunder yang diduga sebagai akibat koevolusi atau transfer genetik dari tumbuhan inang ke dalam mikroba endofit (Kusari et al. 2012). Tanaman obat telah diketahui merupakan sumber potensial kapang endofit yang memiliki kemampuan untuk menghasilkan senyawa kimia bioaktif (Ginting et al. 2013). Mikroba endofit seringkali menghasilkan metabolit sekunder yang sama dengan yang dihasilkan oleh inangnya. Sebagai contoh, tanaman kunyit (Curcuma longa L.) diketahui mempunyai senyawa aktif yaitu kurkumin yang berpotensi sebagai antioksidan (Maehara et al. 2011) dan dilaporkan bahwa kapang endofit dari batang tanaman kunyit (Curcuma longa L.) juga memproduksi senyawa bioaktif yang juga memiliki aktivitas antioksidan (Widowati et al. 2016). Oleh karena itu kapang endofit yang ada di dalam tanaman kayu manis dimungkinkan menghasilkan senyawa metabolit sekunder yang juga memiliki aktivitas antioksidan.

Penelitian mengenai keragaman kapang endofit dan senyawa kimia bioaktif yang dihasilkan kapang endofit dari batang kayu manis ( $C$. burmanni (Nees \& T. Nees) Blume) belum banyak dilakukan. Penelitian ini bertujuan untuk mengisolasi kapang endofit dari batang kayu manis dan mengidentifikasi jenis kapang yang memiliki aktivitas antioksidan dari kapang endofit asal kayu manis.

\section{BAHAN DAN METODE}

\section{Bahan}

Bahan yang digunakan dalam penelitian ini ialah sampel ranting batang kayu manis (C. burmanni (Nees \& T. Nees) Blume) dari perkebunan teh Gunung Mas, Puncak, Bogor, kapang endofit, media Potato Dextrose Agar (PDA), Potato Dextrose Broth (PDB), kertas saring, DPPH (2,2-difenil-1-pikrilhidrazil), alkohol 70\%, $\mathrm{NaOCl}$, metanol p.a, etil asetat, dan bahan kimia lain.

\section{Isolasi kapang endofit}

Sampel ranting tanaman dicuci dengan air mengalir selama 5 menit, kemudian dipotong menjadi beberapa bagian dengan panjang 2-3 cm. Potongan batang disterilisasi permukaan dengan cara direndam dalam alkohol $70 \%$ selama 1 menit, larutan sodium hipoklorit $(\mathrm{NaOCl})$ $5,3 \%$ selama 5 menit dan alkohol $70 \%$ selama 30 detik. Kemudian dibilas dengan aquades steril selama 5 detik dengan tiga kali ulangan dan dikeringkan dengan tisu steril \pm 1 menit di dalam laminar. Potongan sampel kemudian dibelah dengan pisau steril dan diletakkan pada cawan petri yang berisi media PDA yang mengandung kloramfenikol $(250 \mathrm{mg} / \mathrm{L}) \quad$ sebagai penghambat pertumbuhan bakteri. Sebagai 

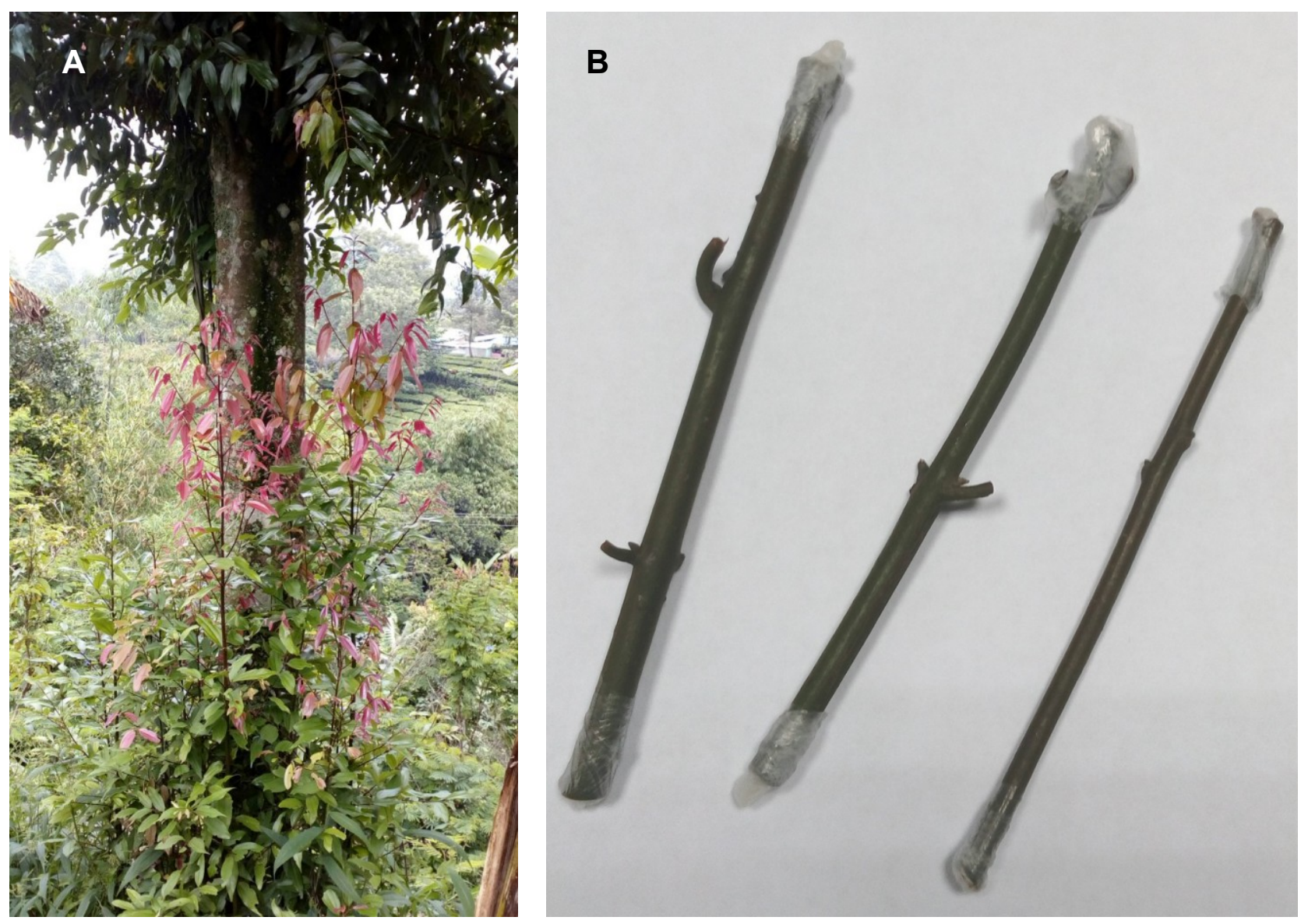

Gambar 1. A). Tanaman kayu manis; B). Ranting kayu manis sumber isolat kapang endofit

kontrol negatif sebanyak $0,5 \mathrm{~mL}$ air steril dari bilasan terakhir disebar pada media PDA dan diinkubasi pada suhu ruang. Kapang yang muncul dipindahkan ke media PDA baru tanpa kloramfenikol dan diinkubasi pada suhu ruang selama 7 hari (Akmalasari et al. 2013).

\section{Fermentasi dan ekstraksi}

Isolat kapang berpotensi antioksidan yang telah diperoleh difermentasi pada media PDB dan diinkubasi goyang dengan shaker pada kecepatan 120 rpm selama 14 hari. Kultur cair disaring menggunakan kertas saring untuk memisahkan filtrat dan biomassa. Filtrat diekstraksi dengan etil asetat sedangkan biomassa dikeringkan dalam oven pada suhu $50^{\circ} \mathrm{C}$ selama 24 jam. Biomassa kering kemudian diekstrak dengan etil asetat sampai semua biomassa terendam oleh pelarut dengan rasio 1:2. Masing-masing ekstrak dikeringkan menggunakan rotary evaporator (Widowati et al. 2016). Ekstrak yang diperoleh kemudian diuji aktivitas antioksidannya. Seleksi dilakukan untuk mengetahui aktivitas antioksidan dari seluruh isolat kapang endofit.

\section{Uji aktivitas antioksidan}

Pengujian aktivitas antioksidan dilakukan dengan metode peredaman radikal bebas dengan reagen DPPH $(2,2-$ difenil-1-pikrilhidrazil) karena paling praktis dan mudah dilakukan dengan keakuratan data yang baik (Molyneux 2004). Seleksi aktivitas antioksidan dengan metode peredaman radikal DPPH (2,2-difenil-1pikrilhidrazil) dilakukan pada konsentrasi 100 $\mu \mathrm{g} / \mathrm{mL}$ untuk masing-masing ekstrak biomassa dan filtrat. Ekstrak dengan konsentrasi $500 \mu \mathrm{g} / \mathrm{mL}$ dipipet $600 \mu \mathrm{L}$ dan direaksikan dengan 0,6 mL DPPH 0,4 mM kemudian ditambahkan metanol pro analisis sampai total campuran menjadi $3 \mathrm{~mL}$. Campuran tersebut selanjutnya diinkubasi dalam waterbath dengan suhu $37^{\circ} \mathrm{C}$ selama 30 menit. Absorbansi diukur menggunakan spektrofotometer pada panjang gelombang $517 \mathrm{~nm}$ (Widowati et al. 2016). Dari hasil absorbansi yang didapat kemudian dihitung daya hambatnya dengan persamaan: 

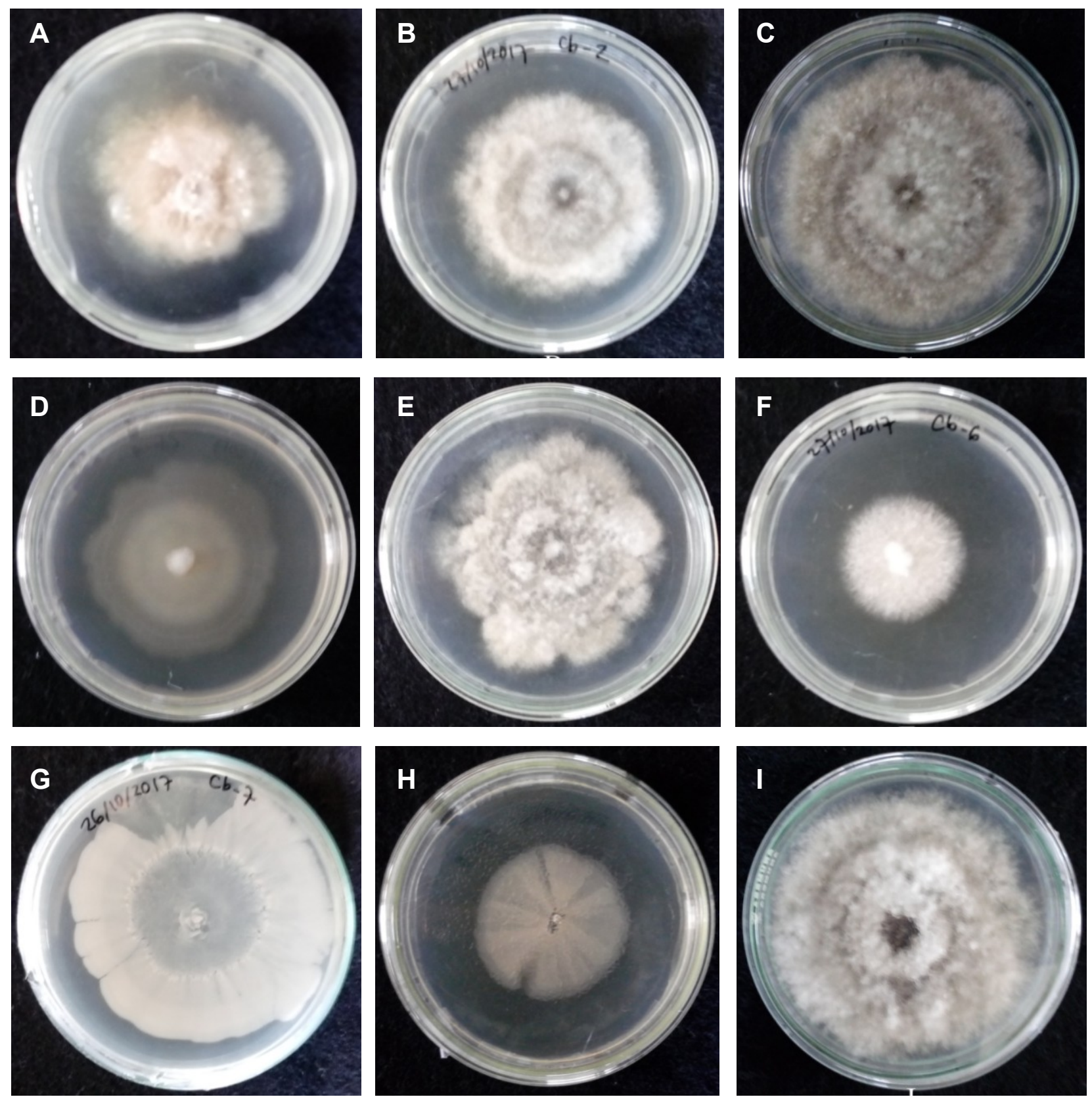

Gambar 2. Isolat kapang endofit dari ranting kayu manis yang tumbuh pada media Potato Dextrose Agar (PDA): A). Cb.Gm.B1; B). Cb.Gm.B2; C). Cb.Gm.B3; D). Cb.Gm.B4; E). Cb.Gm.B5; F). Cb.Gm.B6; G). Cb.Gm.B7; $\mathrm{H})$. Cb.Gm.B8; I). Cb.Gm.B9. Keterangan: $\mathrm{Cb}=$ Cinnamomum burmanni, $\mathrm{Gm}=$ Gunung Mas, $\mathrm{B}=$ Ranting batang

$$
\% \text { Hambatan }=\frac{\mathrm{A}-\mathrm{B}}{\mathrm{A}} \times 100 \%
$$

Keterangan: A: serapan blanko, B: serapan sampel

Ekstrak dengan persentase hambatan tertinggi kemudian diuji lanjut dengan 4 tingkat konsentrasi yaitu $5,10,25$ dan $50 \mu \mathrm{g} / \mathrm{mL}$ untuk mendapatkan nilai $\mathrm{IC}_{50}$. Untuk kontrol positif digunakan vitamin $\mathrm{C}$ (asam askorbat) dengan konsentrasi 3, 6, 9 dan $12 \mu \mathrm{g} / \mathrm{mL}$. $I_{50}$ (Inhibition Concentration 50) dihitung dari perpotongan garis antara $50 \%$ daya hambatan dengan sumbu konsentrasi, kemudian dimasukkan ke dalam persamaan $y=a+b x$ di mana nilai $y=50$ dan nilai $x$ menunjukkan nilai $\mathrm{IC}_{50}$. Pengelompokan aktivitas antioksidan suatu ekstrak berdasarkan pada nilai $I_{50}$. Ekstrak dinyatakan sangat aktif jika nilai $\mathrm{IC}_{50}<10 \mu \mathrm{g} / \mathrm{mL}$, aktif jika nilai $\mathrm{IC}_{50}<100 \mu \mathrm{g} / \mathrm{mL}$, dan tidak aktif jika nilai $\mathrm{IC}_{50}>100 \mu \mathrm{g} / \mathrm{mL}$ (Putri et al. 2013).

\section{Penapisan fitokimia}

Uji penapisan fitokimia meliputi uji 
flavonoid, tannin (Fransworth 1966), dan fenolik (Harborne 1987). Pengujian flavonoid dan tannin, sampel dididihkan dalam air panas selama 5 menit, kemudian dibagi ke dalam dua tabung reaksi. Tabung pertama ditambahkan dengan serbuk magnesium, $\mathrm{HCl}$ pekat dan amil alkohol. Kocok dengan kuat dan biarkan memisah. Terbentuknya warna merah, kuning atau jingga pada lapisan alkohol menunjukkan adanya flavonoid. Tabung kedua ditambahkan larutan $\mathrm{FeCl} 31 \%$ dan timbulnya warna hijau, biru menunjukkan adanya kandungan tannin. Uji fenolik dilakukan dengan menambahkan sampel dengan beberapa tetes $\mathrm{FeCl} 3$ 1\% dalam etanol. Terbentuknya warna hijau, merah, ungu, biru atau hitam kuat menunjukkan adanya fenolik.

\section{Identifikasi kapang endofit}

Identifikasi molekuler terhadap kapang Cb.Gm.B3 diawali dengan mengesktraksi DNA menggunakan ZR Fungal Bacteria DNA Kit (Zymo Research). DNA genom yang didapat diamplifikasi dengan Polymerase Chain Reaction (PCR) dengan menggunakan primer ITS 1 (5'TCCGTAGGTGAACCTGCGG-3') sebagai primer forward dan ITS 4 (5'TCCTCCGCTTATTGATATGC-3') sebagai primer reverse (White et al. 1990). Amplifikasi DNA dilakukan dengan membuat PCR master mix volume $25 \mu \mathrm{L}$ yang mengandung $9,5 \mu \mathrm{L}$ air bebas basa, 12,5 $\mu \mathrm{L}$ 2x My Taq HS Red Mix (Bioline), $1 \mu \mathrm{L} 20$ $\mu \mathrm{mol} / \mu \mathrm{L}$ masing-masing primer ITS 1 dan ITS 4 serta $1 \mu \mathrm{L}$ templat DNA. Reaksi amplifikasi dilakukan sebanyak 35 siklus yang terdiri dari 4 tahapan, yaitu pradenaturasi pada suhu $95^{\circ} \mathrm{C}$ selama 1 menit, denaturasi pada suhu $95^{\circ} \mathrm{C}$ selama 15 detik, annealing pada suhu $52^{\circ} \mathrm{C}$ selama 15 detik, dan ekstensi pada suhu $72^{\circ} \mathrm{C}$ selama 45 detik. Urutan produk PCR dimurnikan dengan menggunakan ZymocleanTM DNA Recovery Kit (Zymo Research). DNA yang dihasilkan dilakukan pembacaan oleh First Base Laboratories, Malaysia. Hasil sekuensing dianalisis dan dicocokkan dengan sekuens DNA kapang yang tersedia di MycoBank (http://www.mycobank.org) dan BLAST (http://www.blast.ncbi.nlm.nih. gov/blast). Analisis filogeni dilakukan dengan metode Neighbor Joining (NJ) dengan program MEGA5 (Tamura et al. 2011), dan pohon filogenetik dibuat menggunakan model Kimura 2-parameter dengan menggunakan replikasi bootstrap 1000.

\section{HASIL DAN PEMBAHASAN}

\section{Isolasi kapang endofit}

Sampel tanaman kayu manis (Gambar 1) sebelumnya diidentifikasi terlebih dahulu di Pusat Penelitian Biologi-LIPI, Cibinong, dan hasil determinasi tumbuhan menyatakan bahwa sampel tersebut adalah $C$. burmanni (Nees \& T. Nees) Blume.

Kemudian dilakukan isolasi kapang
endofit dari ranting kayu manis menggunakan media PDA dan didapatkan 9 isolat kapang endofit (Gambar 2). Kapang endofit yang berhasil diisolasi memiliki deskripsi ciri-ciri dan karakter makroskopis yang bervariasi. Praptiwi et al. (2015) melaporkan bahwa sebanyak 26 kapang endofit berhasil diisolasi dari beberapa bagian tanaman kayu manis, 12 isolat kapang berhasil diisolasi dari batang kayu manis, dan 14 isolat diisolasi dari bagian daun kayu manis. Kapang tersebut 8 isolat diklasifikasikan ke dalam genus Pestalotiopsis, 3 isolat genus Xylaria, 2 isolat genus Colletotrichum, dan 1 isolat genus Fusarium. Dua isolat hanya dapat diidentifikasi sampai tingkat famili, yaitu Dematiaceae, dan 10 isolat hanya dapat diidentifikasi sampai tingkat kelas yaitu Coelomycetes. Akan tetapi tidak ditemukan isolat Ascomycota seperti yang berhasil diisolasi pada penelitian ini. Perbedaan variasi kapang endofit yang diisolasi dari suatu tanaman sangat ditentukan oleh banyak faktor terutama faktor lingkungan. Hal ini menunjukkan bahwa mikroba endofit pada tanaman bervariasi tergantung pada interaksi dengan endofit atau patogen lainnya (Widowati et al. 2016). Kapang endofit yang telah berhasil diisolasi kemudian difermentasi pada media PDB, ekstrak filtrat dan biomassa yang diperoleh kemudian diuji aktivitas antioksidannya untuk mengetahui kapang endofit yang paling berpotensi.

Rendemen ekstrak biomassa secara keseluruhan lebih besar dari rendemen ekstrak filtrat. Kapang isolat Cb.Gm.B7 memiliki rendemen biomassa yang lebih tinggi dari kapang lainnya sedangkan rendemen ekstrak filtrat yang paling tinggi 
Tabel 1. Rendemen ekstrak etil asetat biomasssa dan filtrat

\begin{tabular}{cccc}
\hline No. & Kode isolat & $\begin{array}{c}\text { Rendemen b/b ekstrak } \\
\text { biomassa }(\%)\end{array}$ & $\begin{array}{c}\text { Rendemen b/v ekstrak } \\
\text { filtrat }(\%)\end{array}$ \\
\hline 1 & Cb.Gm.B1 & 1,656 & 0,043 \\
2 & Cb.Gm.B2 & 6,301 & 0,012 \\
3 & Cb.Gm.B3 & 5,714 & 0,028 \\
4 & Cb.Gm.B4 & 19,841 & 0,039 \\
5 & Cb.Gm.B5 & 4,465 & 0,027 \\
6 & Cb.Gm.B6 & 26,702 & 0,012 \\
7 & Cb.Gm.B7 & 38,043 & 0,034 \\
8 & Cb.Gm.B8 & 24,138 & 0,037 \\
9 & Cb.Gm.B9 & 3,921 & 0,045 \\
\hline
\end{tabular}

Tabel 2. Aktivitas hambatan peredaman radikal DPPH dari ekstrak etil asetat filtrat dan biomassa

\begin{tabular}{rrrr}
\hline No. & Kode Isolat & $\begin{array}{r}\text { Aktivitas hambatan } \pm \text { SD } \\
\text { ekstrak filtrat }(\%)\end{array}$ & $\begin{array}{c}\text { Aktivitas hambatan } \pm \text { SD } \\
\text { ekstrak biomassa }(\%)\end{array}$ \\
\hline 1 & Cb.Gm.B1 & $0,196 \pm 0,136$ & $11,488 \pm 0,065$ \\
2 & Cb.Gm.B2 & $52,157 \pm 6,412$ & $4,520 \pm 0,791$ \\
3 & Cb.Gm.B3 & $90,549 \pm 0,580$ & $5,009 \pm 3,979$ \\
4 & Cb.Gm.B4 & $3,176 \pm 0,311$ & $4,520 \pm 0,783$ \\
5 & Cb.Gm.B5 & $90,314 \pm 0,359$ & $3,352 \pm 1,534$ \\
6 & Cb.Gm.B6 & $4,235 \pm 1,326$ & $6,704 \pm 2,121$ \\
7 & Cb.Gm.B7 & $1,333 \pm 0,801$ & $5,838 \pm 1,013$ \\
8 & Cb.Gm.B8 & $6,471 \pm 2,041$ & $6,893 \pm 1,765$ \\
9 & Cb.Gm.B9 & $91,137 \pm 0,180$ & $4,670 \pm 0,920$ \\
\hline
\end{tabular}

adalah isolat Cb.Gm.B9 (Tabel 1). Ekstrak biomassa dan filtrat yang diperoleh kemudian ditapis aktivitas antioksidannya untuk mengetahui isolat yang memiliki potensi aktivitas antioksidan yang tinggi. Penapisan dilakukan menggunakan satu konsentrasi yaitu $100 \mu \mathrm{g} / \mathrm{mL}$ sehingga bisa didapat data aktivitas hambatannya.

Persentase hambatan ekstrak etil asetat pada konsentrasi $100 \mu \mathrm{g} / \mathrm{mL}$ yang memiliki nilai tinggi adalah ekstrak filtrat dari isolat Cb.Gm.B3, Cb.Gm.B5 dan Cb.Gm.B9 dengan persentase hambatan masingmasing yaitu $90,549 \pm 0,580 ; 90,314 \pm$ 0,359 dan $91,137 \pm 0,180 \%$. Sedangkan persentase hambatan untuk ekstrak biomassa semua di bawah 50 persen. Ekstrak dari filtrat isolat Cb.Gm.B9 menunjukkan nilai hambatan tertinggi $(91,137 \pm 0,180 \%)$, sedangkan nilai hambatan ekstrak filtrat terendah ditunjukkan oleh isolat Cb.Gm.B1 (0,196 $\pm 0,136 \%)$. Persentase hambatan tertinggi dari ekstrak biomassa ditunjukkan oleh isolat Cb.Gm.B1 $(11,488 \pm 0,065 \%)$, sedangkan nilai hambatan terendah diperoleh dari ekstrak biomassa isolat Cb.Gm.B5 (3,352 $\pm 1,534 \%)$ (Tabel 2).

Untuk memastikan isolat yang akan diuji lebih lanjut kemudian dilakukan pengujian aktivitas antioksidan terhadap ekstrak filtrat dari isolat Cb.Gm.B3, Cb.Gm.B5 dan Cb.Gm.B9 dengan metode peredaman radikal bebas menggunakan DPPH dengan empat konsentrasi 5, 10, 25 dan $50 \mu \mathrm{g} / \mathrm{mL}$ untuk mencari $\mathrm{IC}_{50}$-nya. Sebagai kontrol positif digunakan vitamin $\mathrm{C}$ (asam askorbat) pada konsentrasi 3, 6, 9 dan $12 \mu \mathrm{g} / \mathrm{mL}$.

Persentase hambatan ekstrak etil asetat pada konsentrasi $100 \mu \mathrm{g} / \mathrm{mL}$ yang memiliki nilai tinggi adalah ekstrak filtrat dari isolat Cb.Gm.B3, Cb.Gm.B5 dan Cb.Gm.B9. Ekstrak filtrat dari isolat Cb.Gm.B3, Cb.Gm.B5 dan Cb.Gm.B9 dinyatakan aktif sebagai antioksidan, sedangkan untuk ekstrak biomassa dinyatakan tidak aktif sebagai antioksidan karena persentase hambatan untuk ekstrak biomassa semua di bawah $50 \%$. Aktivitas antioksidan dari bahan yang diuji dinyatakan aktif bila menghambat radikal bebas lebih dari $80 \%$, dinyatakan 
Tabel 3. Aktivitas antioksidan $\left(\mathrm{IC}_{50}\right)$ isolat Cb.Gm.B3, Cb.Gm.B5, Cb.Gm.B9

\begin{tabular}{|c|c|c|c|c|}
\hline No. & Kode Isolat & $\begin{array}{c}\text { Konsentrasi } \\
(\mu \mathrm{g} / \mathrm{mL})\end{array}$ & $\begin{array}{c}\text { Persen } \\
\text { Inhibisi (\%) }\end{array}$ & $\begin{array}{c}\mathrm{IC}_{50} \pm \mathrm{SD} \\
(\mu \mathrm{g} / \mathrm{mL})\end{array}$ \\
\hline 1 & Cb.Gm.B3 & $\begin{array}{c}5 \\
10 \\
25 \\
50\end{array}$ & $\begin{array}{l}37,444 \\
47,309 \\
70,852 \\
86,323\end{array}$ & $13,219 \pm 0,755$ \\
\hline 2 & Cb.Gm.B5 & $\begin{array}{c}5 \\
10 \\
25 \\
50\end{array}$ & $\begin{array}{l}27,803 \\
42,937 \\
68,386 \\
82,623\end{array}$ & $17,833 \pm 0,018$ \\
\hline 3 & Cb.Gm.B9 & $\begin{array}{c}5 \\
10 \\
25 \\
50\end{array}$ & $\begin{array}{l}16,816 \\
38,229 \\
69,283 \\
84,753\end{array}$ & $20,902 \pm 0,042$ \\
\hline 4 & Vitamin C & $\begin{array}{c}3 \\
6 \\
9 \\
12\end{array}$ & $\begin{array}{l}38,004 \\
82,063 \\
96,300 \\
96,749\end{array}$ & $3,049 \pm 0,044$ \\
\hline
\end{tabular}

Keterangan: $\mathrm{Cb}=$ Cinnamomum burmanni, $\mathrm{Gm}=$ Gunung Mas, $\mathrm{B}=$ Ranting batang

sedang keaktifannya bila menghambat 50 $80 \%$ dan dinyatakan tidak aktif bila menghambat kurang dari 50\% (Widowati et al. 2016). Hasil pada Tabel 2 menunjukkan bahwa nilai persentase inhibisi filtrat lebih besar dibandingkan dengan biomassa, hal ini karena senyawa aktif antioksidan yang dihasilkan lebih banyak terdapat di dalam filtrat (ekstraseluler) dibandingkan di biomassa (intraseluler) (Widowati et al. 2016). Pengujian aktivitas antioksidan dengan metode peredaman radikal DPPH didasarkan pada kemampuan senyawa aktif antiokasidan untuk meredam aktivitas radikal DPPH yang berwarna ungu menjadi bentuk senyawa stabil non-radikal yang berwarna kuning.

Hasil penghitungan $\mathrm{IC}_{50}$ menunjukkan bahwa nilai $\mathrm{IC}_{50}$ terkecil dari ekstrak filtrat isolat Cb.Gm.B3 sebesar 13,219 $\pm 0,755$ $\mu \mathrm{g} / \mathrm{mL}$ (Tabel 3). Namun demikian nilai $\mathrm{IC}_{50}$ dari ekstrak filtrat isolat Cb.Gm.B3 masih lebih tinggi dibandingkan dengan $\mathrm{IC}_{50}$ vitamin $C$ yaitu sebesar $3,049 \pm 0,044$ $\mu \mathrm{g} / \mathrm{mL}$.

Nilai $\mathrm{IC}_{50}$ berbanding terbalik dengan aktivitas antioksidannya. Semakin kecil nilai $\mathrm{IC}_{50}$ maka aktivitas antioksidannya semakin kuat. Berdasarkan nilai $\mathrm{IC}_{50}$ yang diperoleh, aktivitas antioksidan yang terbaik diantara ketiga isolat yang diuji adalah ekstrak etil asetat filtrat dari isolat Cb.Gm.B3, meskipun masih lebih rendah dibandingkan dengan
Tabel 4. Hasil uji penapisan fitokimia ekstrak etil asetat filtrat isolat CB.Gm.B3

\begin{tabular}{lc}
\hline Senyawa kimia & Kandungan \\
\hline Flavonoid & + \\
Tannin & + \\
Fenolik & + \\
\hline
\end{tabular}

Keterangan: $(+)=$ terdeteksi

aktivitas antioksidan dari vitamin C. Semakin kecil nilai $I_{50}$ maka senyawa uji tersebut akan semakin efektif dalam penangkap radikal bebas (Cholisoh dan Utami 2008). Suatu senyawa dikelompokkan ke dalam sangat aktif sebagai antioksidan jika nilai $\mathrm{IC}_{50}<10$, aktif jika nilai $\mathrm{IC}_{50}<100$ dan tidak aktif jika nilai $\mathrm{IC}_{50}>100 \mu \mathrm{g} / \mathrm{mL}$ (Putri et al. 2013). Dengan demikian ekstrak etil asetat filtrat dari isolat Cb.Gm.B3 termasuk ke dalam kelompok antioksidan yang aktif.

Hasil uji penapisan fitokimia dari ekstrak filtrat etil asetat isolat Cb.Gm.B3 menunjukkan bahwa di dalam ekstrak filtrat etil asetat Cb.Gm.B3 tersebut ditemukan adanya senyawa flavonoid, tannin dan fenolik (Tabel 4).

Aktivitas biologis dari suatu ekstrak erat kaitannya dengan senyawa kimia yang dikandungnya. Dari hasil penapisan fitokimia diketahui bahwa ekstrak filtrat kapang endofit isolat CB.Gm.B3 mengandung golongan senyawa flavonoid, tannin dan 




Gambar 3. Pohon filogenetik isolat Cb.Gm.B3 menggunakan metode Neighbour-Joining (NJ)

fenolik (Tabel 4). Senyawa fenol dan flavonoid dilaporkan memiliki peranan positif terhadap aktivitas antioksidan, dimana semakin tinggi kadar senyawa tersebut maka akan semakin tinggi pula aktivitas antioksidannya (Ghasemzadeh dan Ghasemzadeh 2011). Senyawa flavonoid juga dilaporkan mempunyai kemampuan sebagai penangkap radikal bebas dan menghambat oksidasi lipid (Banjarnahor dan Artanti 2014), sedangkan senyawa tannin yang merupakan salah satu komponen fenolik diketahui memiliki aktivitas antioksidan (Saxena et al. 2013), bahkan lebih efektif dalam menangkap radikal peroksil daripada senyawa fenolik sederhana sehingga tannin bisa dipertimbangkan sebagai antioksidan biologi yang potensial (Gagola et al. 2014).

\section{Identifikasi Molekuler Isolat Cb.Gm.B3}

Identifikasi isolat kapang dilakukan secara molekuler berdasarkan analisis genetika secara parsial pada lokus ITS (Internal Transcribed Spacer) ribosomal DNA kapang. Berdasarkan data ITS, isolat Cb.Gm.B3 diidentifikasi sebagai Neofusicoccum parvum. Hasil BLAST menunjukkan kekerabatan yang tinggi dengan N. parvum isolat PEL23, Accession no: KY053054.1 [Max score: 1026; Total score: 1026; Query coverage: 100\%; Evalue: 0.0; Max identities: $100 \%$ ].
Analisis lanjut menggunakan pohon kekerabatan filogenetik menunjukkan bahwa isolat Cb.Gm.B3 sangat dekat kekerabatannya dengan $N$. parvum dengan nilai bootstrap 92\% (Gambar 3). Berdasarkan hasil ini dilihat kekerabatannya dengan beberapa spesies kapang dari tanaman hutan yang telah berhasil dihimpun oleh Lopes et al. (2016) untuk membuat pohon filogenetiknya. $N$. parvum merupakan kapang yang bersimbiosis dengan tanaman sebagai endofit atau fitopatogen. Beberapa spesies Neofusicoccum adalah patogen bagi suatu tanaman, tetapi spesies yang lain mempunyai hubungan simbiosis mutualistik dengan inangnya. Perubahan mikroba endofit menjadi fase patogen bisa diakibatkan karena adanya tekanan seperti tekanan kekeringan, fluktuasi suhu ekstrim, kekurangan nutrisi dan kerusakan mekanis (Slippers dan Wingfield 2007). Sebagai contoh $N$. parvum adalah yang paling banyak ditemukan di tanaman Tibouchina urvilleana, akan tetapi memiliki sifat tidak agresif. Berbeda dengan N. mangiferae yang walaupun sedikit ditemukan pada inang yang sama akan tetapi memiliki tingkat patogenitas yang sangat tinggi (Heath et al. 2011).

\section{KESIMPULAN}

Bioproduksi kapang endofit hasil 
isolasi dari batang kayu manis terbukti memiliki aktivitas antioksidan. Hasil bioproduksi kapang endofit Cb.Gm.B3 memiliki aktivitas antioksidan tertinggi yaitu $13,219 \pm 0,755 \mu \mathrm{g} / \mathrm{mL}$. Hasil identifikasi molekuler terhadap isolat kapang tersebut diketahui memiliki tingkat kemiripan yang tinggi dengan $N$. parvum isolat PEL23 (No. aksesi: KY053054.1).

\section{SARAN}

Perlu dilakukan isolasi dan identifikasi senyawa kimia hasil bioproduksi kapang endofit Cb.Gm.B3 untuk mengetahui struktur kimia senyawa aktif tersebut.

\section{UCAPAN TERIMA KASIH}

Terima kasih kepada Kementerian Riset, Teknologi dan Pendidikan Tinggi (Kemenristekdikti) yang telah memberikan bantuan beasiswa melalui beasiswa Program Gelar tahun 2016 (SK Nomor 338/M/KPT/2016) dan mendanai penelitian ini.

\section{DAFTAR PUSTAKA}

Akmalasari I, Purwati ES, Dewi RS (2013) Isolasi dan identifikasi jamur endofit tanaman manggis (Garcinia mangostana L.). Biosfera 30:82-89. Doi: 10.20884/1.mib.2013.30.2.131

Banjarnahor S, Artanti N (2014) Antioxidant properties of flavonoids. Med J Indones 23:239-244. doi: $10.13181 / \mathrm{mji} . \mathrm{v} 23 \mathrm{i} 4.1015$

Cholisoh Z, Utami W (2008) Aktivitas penangkapan radikal ekstrak etanol 70\% biji Jengkol (Archidendron jiringa). Pharmacon 9:33-40

Dai C, Yu B, Li X (2008) Screening of endophytic fungi that promote the growth of Euphorbia pekinensis. Afr J Biotechnol 7:3505-3510

Dudeja SS, Giri R, Saini R, Suneja-Madan P, Kothe $E$ (2012) Interaction of endophytic microbes with legumes. J Basic Microbiol 52:248-260. doi: 10.1002/jobm.201100063

Ferry Y (2013) Prospek pengembangan kayu manis (Cinnamomum burmanii L) di Indonesia. SIRINOV 1:11-20

Fransworth NR (1966) Biological and phytochemical screening of plant. $\mathrm{J}$
Pharm Sci 55:225-265. doi: 10.1002/jps.2600550302

Gagola C, Suryanto E, Wewengkang D (2014) Aktivitas antioksidan dari ekstrak fenolik cortex umbi ubi kayu (Manihot esculenta) daging putih dan daging kuning yang diambil dari kota Melonguane Kabupaten Kepulauan Talaud. Pharmacon J IImiah Farmasi 3:127-133

Ghasemzadeh A, Ghasemzadeh N (2011) Flavonoids and phenolic acids: Role and biochemical activity in plants and human. J Med Plants Res 5:66976703. doi: 10.5897/JMPR11.1404

Ginting RCB, Sukarno N, Widyastuti U, Darusman LK, Kanaya S (2013) Diversity of endophytic fungi from red ginger (Zingiber officinale Rosc.) plant and their inhibitory effect to Fusarium oxysporum plant pathogenic fungi. Hayati 20:127-137. doi: 10.4308/hjb.20.3.127

Harborne JB (1987) Metode Fitokimia: Penuntun Cara Modern Menganalisa Tumbuhan. Edisi kedua. Terjemahan. Padmawinata K, Soediro I, Niksolihin S. Penerbit ITB, Bandung

Heath RN, Roux J, Slippers B, Drenth A, Pennycook SR, Wingfield BD, Wingfield MJ (2011) Occurrence and pathogenicity of Neofusicoccum parvum and $N$. mangiferae on ornamental Tibouchina species. For Path 41:48-51. doi: 10.1111/j.14390329.2009.00635.x

Jakhetia V, Patel R, Khatri P, Pahuja N, Garg S, Pandey A, Sharma S (2010) Cinnamon: A pharmacological review. J Adv Sci Res 1:19-23

Kusari S, Hertweck C, Spiteller M (2012) Chemical ecology of endophytic fungi: Origins of secondary metabolites. Chem Biol 19:792-798. doi: 10.1016/j.chembiol.2012.06.004

Lopes A, Barradas C, Phillips AJL, Alves A (2016) Diversity and phylogeny of Neofusicoccum species occurring in forest and urban environments in Portugal. Mycospere 7:906-920. doi: 10.5943/mycosphere/si/1b/10

Maehara S, Ikeda M, Haraguchi H, Kitamura C, Nagoe T, Ohashi K, Shibuya H (2011) Microbial conversion of curcumin into colorless 
hydroderivatives by the endophytic fungus Diaporthe sp. associated with Curcuma longa. Chem Pharm Bull 59:1042-1044. doi: 10.1248/cpb. 59.1042

Molyneux P (2004) The use of the stable free radical diphenylpicryl-hydrazyl (DPPH) for estimating antioxidant activity. Songklanakarin J Sci Technol 26:211-219

Praptiwi, llyas M, Wulansari D, Agusta A (2015) Antibacterial screening of the culture of endophytic fungal extracts isolated from cinnamon stick (Cinnamomum burmanni [Nees \& $\mathrm{T}$. Nees] Blume). J Teknologi Indones 38:33-41. doi: 10.14203/jti.v38i1.159

Priani SE, Darusman F, Humanisya H (2014) Formulasi sediaan emulgel antioksidan mengandung ekstrak etanol kulit batang kayu manis (Cinnamomum burmanni Nees Ex. BI.). Prosiding SNaPP 2014 Sains, Teknologi dan Kesehatan 4:103-110

Putri IJ, Fauziyah, Elfita (2013) Aktivitas antioksidan daun dan biji buah nipah (Nypa fruticans) asal pesisir Banyuasin Sumatera Selatan dengan metode DPPH. Maspari J 5:16-21

Saxena M, Saxena J, Nema R, Singh D,
Gupta A (2013) Phytochemistry of medicinal plants. J Pharmacogn Phytochem 1:168-182

Slippers B, Wingfield MJ (2007) Botryosphaeriaceae as endophytes and latent pathogens of woody plants: diversity, ecology and impact. Fungal Biol Rev 21:90-106. doi: 10.1016/ j.fbr.2007.06.002

Tamura K, Peterson D, Peterson N, Stecher G, Nei M, Kumar S (2011) MEGA5: molecular evolutionary genetics analysis using maximum likelihood, evolutionary distance, and maximum parsimony methods. Mol Biol Evol 28:2731-2739. doi: 10.1093/molbev/msr121

White TJ, Bruns T, Lee S, Taylor I (1990) Amplification and direct sequencing of fungal ribosomal RNA genes for phylogenetics. Pp 315-322. In: Innis MA, Gelfand DH, Sninsky JJ, White TJ, (Eds). PCR Protocols: A Guide to Method and Applications. Academic Press, New York

Widowati T, Bustanussalam, Sukiman $\mathrm{H}$, Simanjuntak P (2016) Isolasi dan identifikasi kapang endofit dari tanaman kunyit (Curcuma longa L.) sebagai penghasil antioksidan. Biopropal Indust 7:9-16 